\title{
Nitrous oxide emissions from the Arabian Sea: A synthesis
}

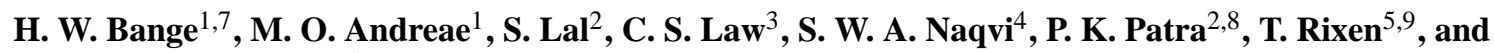 \\ R. C. Upstill-Goddard ${ }^{6}$ \\ ${ }^{1}$ Max Planck Institute for Chemistry, Mainz, Germany \\ ${ }^{2}$ Physical Research Laboratory, Ahmedabad, India \\ ${ }^{3}$ Plymouth Marine Laboratory, Plymouth, United Kingdom \\ ${ }^{4}$ National Institute of Oceanography, Dona Paula, Goa, India \\ ${ }^{5}$ University of Hamburg, Hamburg, Germany \\ ${ }^{6}$ University of Newcastle, Newcastle upon Tyne, United Kingdom \\ ${ }^{7}$ now at Institute for Marine Research, Kiel, Germany \\ ${ }^{8}$ now at Frontier Research System for Global Change, Yokohama, Japan \\ ${ }^{9}$ now at Center for Tropical Marine Ecology, Bremen, Germany
}

Received: 7 August 2001 - Published in Atmos. Chem. Phys. Discuss.: 3 September 2001

Revised: 22 November 2001 - Accepted: 3 December 2001 - Published: 28 December 2001

\begin{abstract}
We computed high-resolution $\left(1^{\circ}\right.$ latitude $\times 1^{\circ}$ longitude) seasonal and annual nitrous oxide $\left(\mathrm{N}_{2} \mathrm{O}\right)$ concentration fields for the Arabian Sea surface layer using a database containing more than 2400 values measured between December 1977 and July 1997. $\mathrm{N}_{2} \mathrm{O}$ concentrations are highest during the southwest (SW) monsoon along the southern Indian continental shelf. Annual emissions range from 0.33 to $0.70 \mathrm{Tg} \mathrm{N}_{2} \mathrm{O}$ and are dominated by fluxes from coastal regions during the $\mathrm{SW}$ and northeast monsoons. Our revised estimate for the annual $\mathrm{N}_{2} \mathrm{O}$ flux from the Arabian Sea is much more tightly constrained than the previous consensus derived using averaged in-situ data from a smaller number of studies. However, the tendency to focus on measurements in locally restricted features in combination with insufficient seasonal data coverage leads to considerable uncertainties of the concentration fields and thus in the flux estimates, especially in the coastal zones of the northern and eastern Arabian Sea. The overall mean relative error of the annual $\mathrm{N}_{2} \mathrm{O}$ emissions from the Arabian Sea was estimated to be at least $65 \%$.
\end{abstract}

\section{Introduction}

Nitrous oxide $\left(\mathrm{N}_{2} \mathrm{O}\right)$ is an atmospheric trace gas that influences, directly and indirectly, the Earth's climate (Prather et al., 2001). Source estimates indicate that the world's oceans

Correspondence to: H. W. Bange (hbange@ifm.uni-kiel.de) play a major role in the global budget of atmospheric $\mathrm{N}_{2} \mathrm{O}$ (Seitzinger et al., 2000). Upwelling regions, such as the eastern tropical Pacific and the Arabian Sea, are sites of high $\mathrm{N}_{2} \mathrm{O}$ production via denitrification and/or nitrification processes that occur at the boundaries of the oxygen depleted water masses (Codispoti et al., 1992). Following the studies of Law and Owens (1990) and Naqvi and Noronha (1991), it has been speculated that the Arabian Sea, especially its upwelling-dominated northwestern part, represents a hot spot for $\mathrm{N}_{2} \mathrm{O}$ emissions and makes a substantial contribution to the global budget of atmospheric $\mathrm{N}_{2} \mathrm{O}$. However, the situation is apparently somewhat more complicated, because recent data show seasonal $\mathrm{N}_{2} \mathrm{O}$ emissions from the continental shelf area of India also to be important (Naqvi et al., 2000). Previous $\mathrm{N}_{2} \mathrm{O}$ flux estimates are compromised by significant temporal and spatial biases. Moreover, we recognize that in efforts to model global oceanic $\mathrm{N}_{2} \mathrm{O}$ emissions, the Arabian Sea appears to be under-represented mainly owing to the relatively low spatial resolution of the applied models and/or missing data from this region (Nevison et al., 1995; Seitzinger et al., 2000; Suntharalingam and Sarmiento, 2000). Here we present a comprehensive compilation of $\mathrm{N}_{2} \mathrm{O}$ measurements from the Arabian Sea surface layer from 1977 to 1997 . These data were used to calculate mean seasonal and annual climatological $\mathrm{N}_{2} \mathrm{O}$ fields with a $1^{\circ}$ latitude $\times 1^{\circ}$ longitude resolution. On the basis of the $\mathrm{N}_{2} \mathrm{O}$ surface concentration fields, $\mathrm{N}_{2} \mathrm{O}$ emissions from the Arabian Sea were reassessed. 
Table 1. Overview of the $\mathrm{N}_{2} \mathrm{O}$ Source Data

\begin{tabular}{lllrl}
\hline Arabian Sea Region & Cruise Dates & Method & N & References \\
\hline West, Central & Dec 1977-Jan 1978 & Con & 668 & Weiss et al. (1992) $^{a}$ \\
Northwest, Central & Sep 1986 & Dis & 19 & Law and Owens (1990) \\
East, Central & Dec 1988 & Dis & 15 & Naqvi and Noronha (1991) \\
East, Central & Apr-May 1994, & Dis & 125 & Lal and Patra (1998) $^{b}$ \\
& Feb-Mar, Jul-Aug 1995, & & & \\
& Aug 1996, Feb 1997 & & & \\
Northwest, Central & Sep, Nov-Dec 1994 & Dis & 47 & Upstill-Goddard et al. (1999) $^{\text {Northwest, Central }}$ \\
& May, Jul-Aug 1995, & Con & 1569 & Bange et al. (1996a) \\
& Mar, May-Jul 1997 & & & Bange et al. (2000) \\
East & Jul 1995 & Dis & 20 & Naqvi et al. (1998) \\
\hline
\end{tabular}

Con stands for continuous measurements.

Dis stands for measurements of discrete samples. $\mathrm{N}$ stands for number of data points.

${ }^{a}$ Data are available from the anonymous ftp site cdiac.esd.ornl.edu (subdirectory /pub/ndp044) at the Carbon Dioxide Information Analysis Center in Oak Ridge, Tennessee.

${ }^{b}$ Data are included in the JGOFS-India data compilation on CD-ROM available from the Indian National Oceanographic Data Centre, Goa, India (ocean@csnio.ren.nic.in).

${ }^{c}$ Data are available from the German JGOFS data management (http://www.ifm.uni-kiel.de/jgofs/dm).

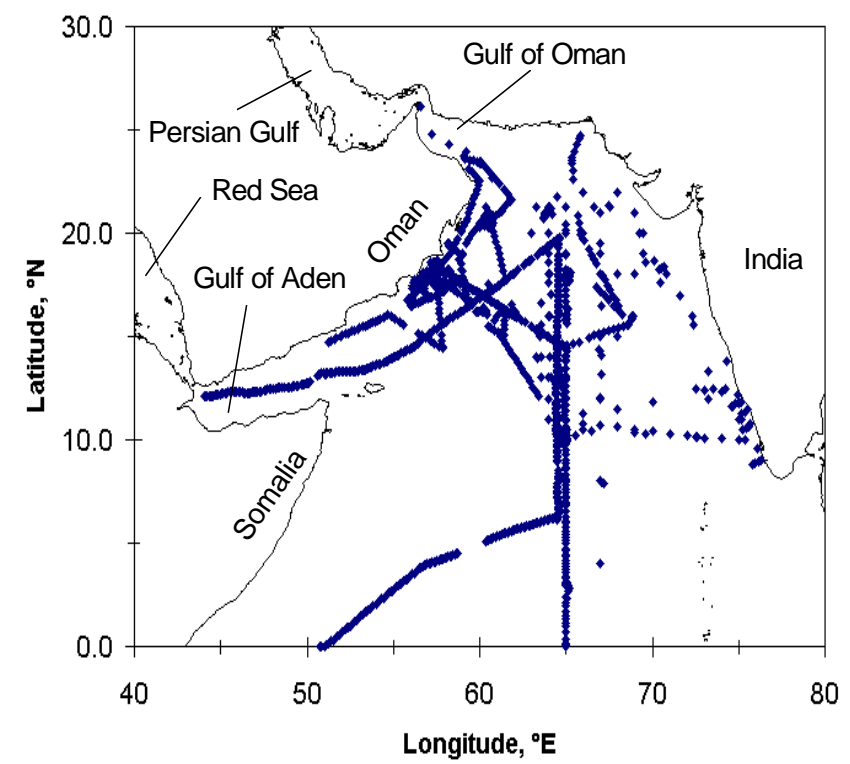

Fig. 1. Map of the Arabian Sea with locations of the $\mathrm{N}_{2} \mathrm{O}$ measurements in the surface layer used in our study (see Table 1).

\section{Data sources}

For our study we compiled $\mathrm{N}_{2} \mathrm{O}$ measurements from $0-10 \mathrm{~m}$ water depth within the study area $\left(44^{\circ}-80^{\circ} \mathrm{E}, 0^{\circ}-27^{\circ} \mathrm{N}\right)$ excluding the Persian Gulf and the Red Sea (Fig. 1). The majority of the data were collected during individual national contributions to the international Joint Global Ocean Flux Study (JGOFS) - Arabian Sea Process Study between 1994 and 1997. Pre-JGOFS data were from cruises in 1977/1978, 1986, and 1988. An overview of the data sources is given in Table 1. (Unfortunately, data from the 1992 Netherlands Indian Ocean Program were unavailable for this reassessment.) $\mathrm{N}_{2} \mathrm{O}$ concentrations are typically reported in nmol $\mathrm{L}^{-1}$, however, the data listed in Weiss et al. (1992) are in dry mole fractions. We recalculated the Weiss et al. (1992) $\mathrm{N}_{2} \mathrm{O}$ concentrations with the reported water temperature, a mean seasonal salinity of 35.75 , as calculated from climatological salinity data (see below), and an atmospheric pressure of $1 \mathrm{~atm}$ (Weiss and Price, 1980). We are aware that this procedure introduces an additional error; however, the dependence of the $\mathrm{N}_{2} \mathrm{O}$ solubility on salinity and pressure is small and the resulting uncertainty of about $\pm 1 \%$ is acceptable for our purposes.

Weekly averaged wind speeds for the period July 1987 to December 1995 were derived from satellite-based Special Sensor Microwave / Imager measurements by using an algorithm developed by Schlüssel (1995) (see Appendix A). Weekly composites of $18 \mathrm{~km} \times 18 \mathrm{~km}$ gridded, day and night multichannel sea surface temperatures (SSTs) satellite data for the period 1986 to 1995 were provided by the Physical Oceanography Distributed Active Archive Center of the Jet Propulsion Laboratory, California Institute of Technology, Pasadena, California (http://podaac.jpl.nasa.gov:2031/ DATASET_DOCS/avhrr_wkly_mcsst.html). Monthly climatological salinities with a resolution of $1^{\circ} \times 1^{\circ}$ were obtained 

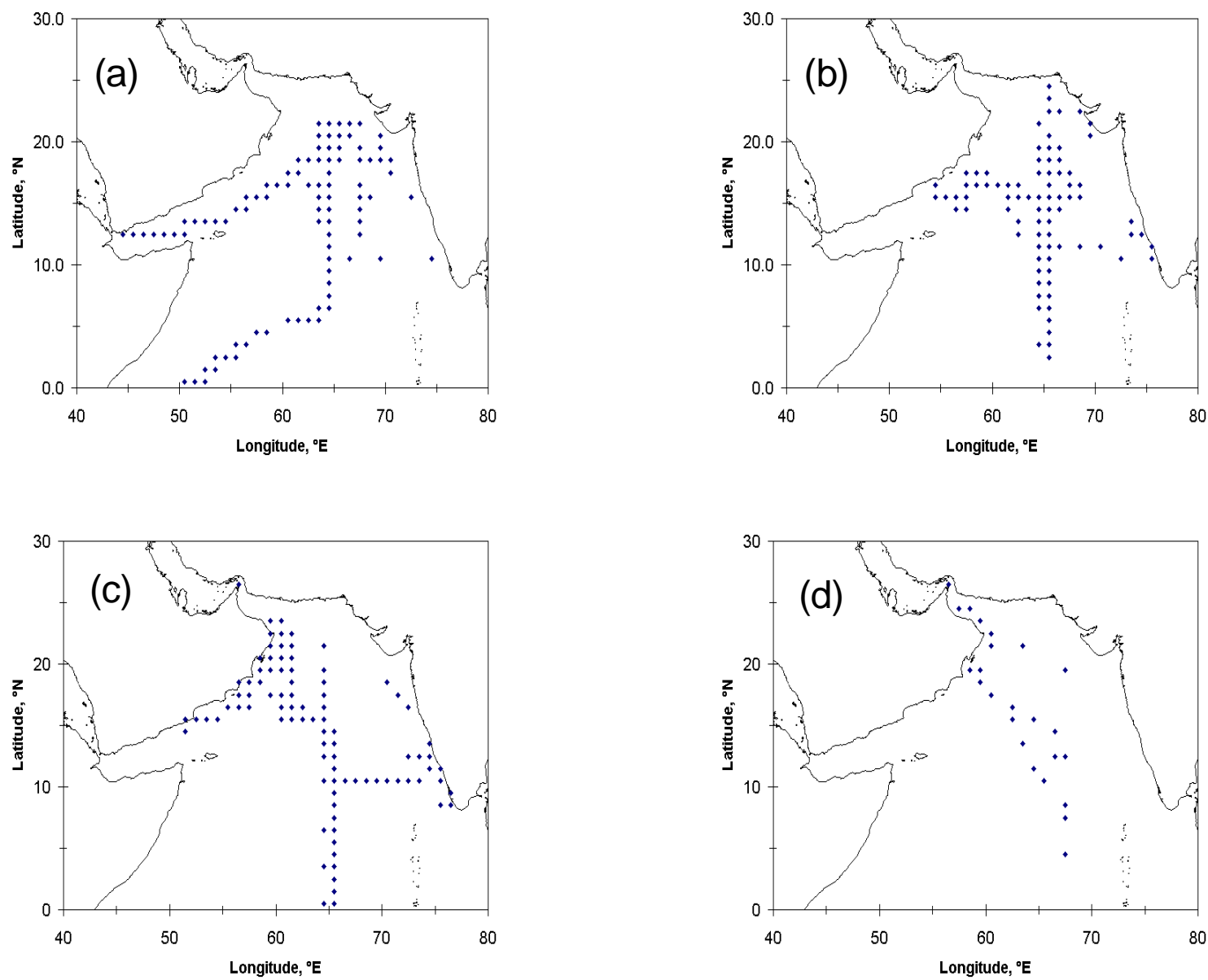

Fig. 2. Seasonal maps of $\mathrm{N}_{2} \mathrm{O}$ pixels. (a) DJF, (b) MAM, (c) JJA, and (d) SON.

from the World Ocean Atlas 1998 (http://www.nodc.noaa. gov/OC5/data_woa.html).

\section{$3 \quad \mathbf{N}_{2} \mathbf{O}$ fields}

For the calculation of the $\mathrm{N}_{2} \mathrm{O}$ fields we applied a modified procedure originally described by Conkright et al. (1994) and further developed by Kettle et al. (1999). The original data sets were combined to form a database with 2463 values. The database was then divided into 12 monthly databases. A statistical checking procedure was implemented, wherein the monthly database values were pooled into $5^{\circ} \times 5^{\circ}$ squares. For each $5^{\circ} \times 5^{\circ}$ square a mean and standard deviation (sd) were calculated and individual data were compared with the mean. Values falling outside 3 times the sd of the mean were omitted and the procedure was repeated until no further values were eliminated. In squares with 3 values or fewer, the checking procedure was omitted and the remaining values accepted. This procedure removed 49 data points. The modified monthly databases were then subdivided into $1^{\circ} \times 1^{\circ}$ squares. Mean $\mathrm{N}_{2} \mathrm{O}$ values (so-called $\mathrm{N}_{2} \mathrm{O}$ pix- els) were calculated from the data in each square. If there was only one value within the square, it was accepted as a pixel. Monthly $\mathrm{N}_{2} \mathrm{O}$ pixel data sets were then combined into four seasonal sets: northeast (NE) monsoon (December to February, DJF), intermonsoon (March to May, MAM), southwest (SW) monsoon (June to August, JJA), and intermonsoon (September to November, SON) (Figs. 2a-d). Finally, the four seasonal sets were combined to form an annual $\mathrm{N}_{2} \mathrm{O}$ pixel set. For the annual and for each of the four seasonal and pixel sets, we calculated means for Arabian Sea biogeographic provinces, i.e. the Northwestern Arabian Upwelling, Indian Monsoon Gyres, and Western India Coastal provinces (INDW) (Longhurst, 1998). The biogeographic means were used to create a $1^{\circ} \times 1^{\circ}$ first-guess field which was smoothed with a 9-point 2-dimensional operator (Shuman, 1957). A $1^{\circ} \times 1^{\circ}$ correction field was computed for each of the seasonal and annual $\mathrm{N}_{2} \mathrm{O}$ pixel data by applying the distance-weighted interpolation scheme of Conkright et al. (1994) (see Appendix A). In order to preclude any smoothing of small-scale features, we reduced the influence radius from $555 \mathrm{~km}$ to $222 \mathrm{~km}$. The correction field was then added to the first-guess field and smoothed (Shu- 

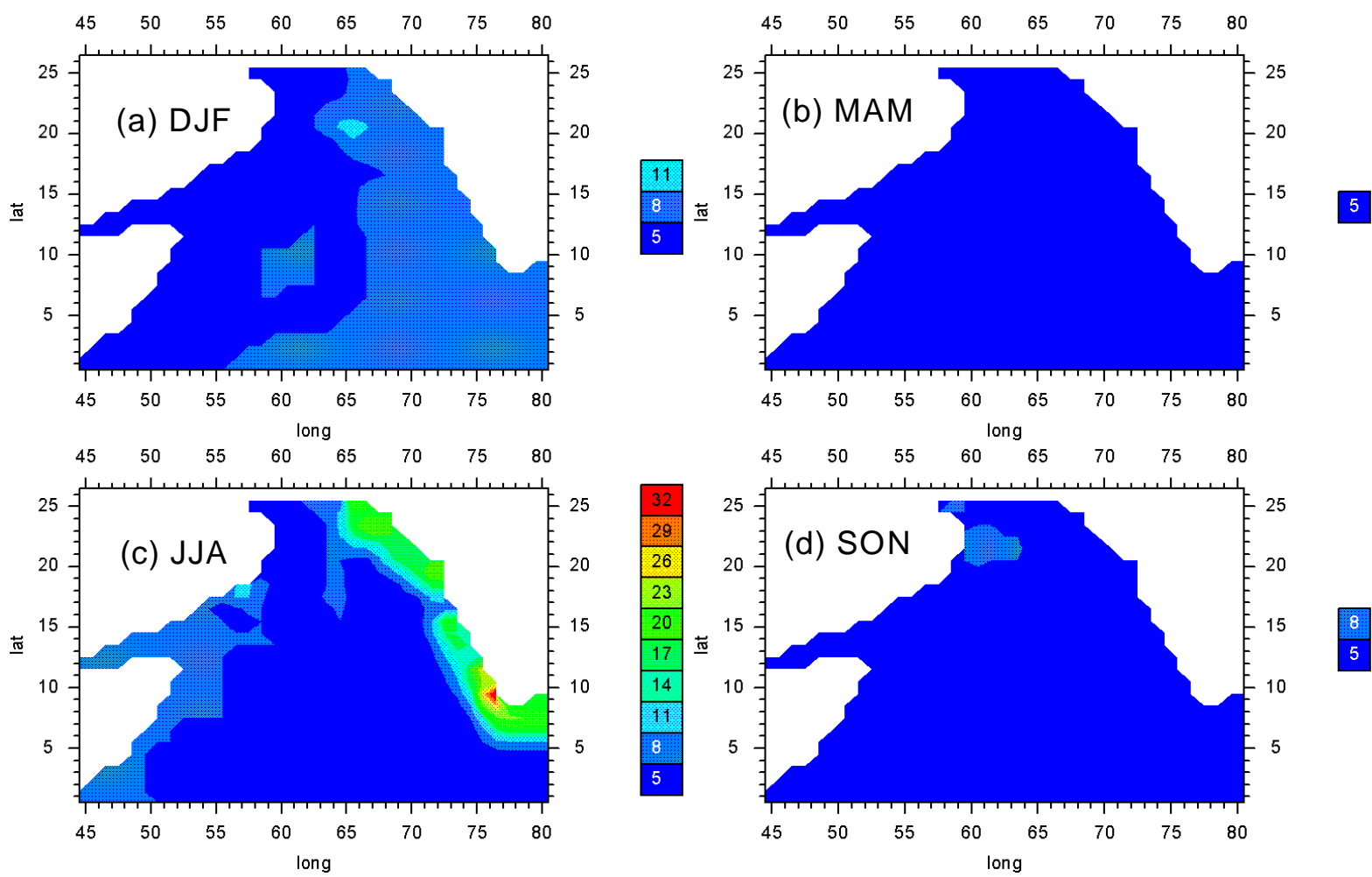

Fig. 3. Seasonal maps of the final $\mathrm{N}_{2} \mathrm{O} 1^{\circ} \times 1^{\circ}$ fields (in nmol $\mathrm{L}^{-1}$ ). (a) DJF, (b) MAM, (c) JJA, and (d) SON. Contour labelling starts with $5 \mathrm{nmol} \mathrm{L}{ }^{-1}$; minimum concentration range is shown in dark blue $\left(5-8 \mathrm{nmol} \mathrm{L}^{-1}\right)$, maximum concentration range is shown in red (> $\left.32 \mathrm{nmol} \mathrm{L}^{-1}\right)$.

man, 1957), yielding the final $1^{\circ} \times 1^{\circ}$ annual and seasonal $\mathrm{N}_{2} \mathrm{O}$ fields. The final seasonal and annual $\mathrm{N}_{2} \mathrm{O}$ concentration fields are available from the German JGOFS data management (http://www.ifm.uni-kiel.de/jgofs/dm).

\section{Air-sea exchange}

The air-sea exchange flux density $(F)$ was parameterized as $F=k_{w}(u)\left(C_{w}-C_{a}\right)$,

where $k_{w}$ is the gas transfer coefficient as a function of wind speed ( $u$ in $10 \mathrm{~m}$ height), $C_{w}$ is the $\mathrm{N}_{2} \mathrm{O}$ seawater concentration, and $C_{a}$ is the equilibrium $\mathrm{N}_{2} \mathrm{O}$ concentration in seawater. $C_{a}$ was calculated using

$C_{a}=\beta(T, S) x^{\prime} P$,

where $x^{\prime}$ is the atmospheric $\mathrm{N}_{2} \mathrm{O}$ dry mole fraction, $P$ is the atmospheric pressure, and $\beta$ is the Bunsen solubility, which is a function of the water temperature $(T)$ and salinity $(S)$ (Weiss and Price, 1980). To calculate $k_{w}$, we used the tri-linear $k_{w}-u$ relationship of Liss and Merlivat (1986) (LM86), the quadratic $k_{w}-u$ relationship for climatological wind data of Wanninkhof (1992) (W92), and the combined linear and quadratic $k_{w}-u$ relationship from Nightingale et al. (2000) (N00) (Equations of the LM86, W92, and N00 approaches are given in Appendix B). $k_{w}$ was adjusted by multiplying with $(S c / 600)^{-n}(n=2 / 3$ for wind speeds $<3.6 \mathrm{~m} \mathrm{~s}^{-1}$ and $n=1 / 2$ for wind speeds $\left.>3.6 \mathrm{~m} \mathrm{~s}^{-1}\right)$ for LM86, $(S c / 660)^{-0.5}$ for W92, and $(S c / 600)^{-0.5}$ for N00, where $S c$ is the Schmidt number for $\mathrm{N}_{2} \mathrm{O}$. Sc was calculated using empirical equations for the kinematic viscosity of seawater (Siedler and Peters, 1986) and the diffusion coefficient of $\mathrm{N}_{2} \mathrm{O}$ in water. The $\mathrm{N}_{2} \mathrm{O}$ diffusion coefficients $\left(\boldsymbol{D}_{N 2 O} \mathrm{O}\right.$ in $\mathrm{m}^{2} \mathrm{~s}^{-1}$ ) were calculated with Eq. (1) derived from the data given in Broecker and Peng (1974) and, alternatively, with the new Eq. (2) derived from a compilation of actual measurements (Rhee, 2000):

$\log _{10} \boldsymbol{D}_{N 2 O}=-1008.28 / R T-5.245$

$\boldsymbol{D}_{N 2 O}=3.16 \times 10^{-6} \exp (-18370 / R T)$,

where $T$ is the water temperature in $K$ and $R$ is the universal gas constant. Equation (1) ist based on 5 measurements of $\mathrm{N}_{2} \mathrm{O}$ diffusion coefficients in water in a temperature range from $14^{\circ}$ to $25^{\circ} \mathrm{C}$ (see compilation by Himmelblau, 1964). Unfortunately, these rather old values (two of them were already published in 1898, the rest was published in 1957) show a considerable scattering, indicating an uncertainty of up to $20 \%$ for values calculated with Eq. (1) (Broecker and Peng, 1974). Equation (2) is based on 49 measurements of 
Table 2. $\mathrm{N}_{2} \mathrm{O}$ fluxes from the Arabian Sea calculated with the $\mathrm{N}_{2} \mathrm{O}$ diffusion coefficient of Broecker and Peng (1974)

\begin{tabular}{lcc}
\hline $\mathrm{N}_{2} \mathrm{O}$ Fields & $\begin{array}{c}\text { Flux } \\
\mathrm{Tg} \mathrm{N}_{2} \mathrm{O}\end{array}$ & $\begin{array}{c}\text { Percentage, } \\
\%\end{array}$ \\
\hline $\mathrm{DJF}$ & $0.08 / 0.13 / 0.19$ & $22 / 25 / 24$ \\
$\mathrm{MAM}$ & $0.01 / 0.01 / 0.02$ & $3 / 2 / 3$ \\
$\mathrm{JJA}$ & $0.25 / 0.33 / 0.51$ & $68 / 65 / 65$ \\
$\mathrm{SON}$ & $0.03 / 0.04 / 0.06$ & $8 / 8 / 8$ \\
Sum & $0.37 / 0.51 / 0.78$ & \\
\hline
\end{tabular}

${ }^{a}$ First value calculated according to LM86; second value calculated according to N00, and third value calculated according to W92.

$\mathrm{N}_{2} \mathrm{O}$ diffusion coefficients in water in the temperature range from $14^{\circ}$ to $95^{\circ} \mathrm{C}$ (see compilation by Rhee, 2000), thus providing a more reasonable fit for the $\mathrm{N}_{2} \mathrm{O}$ diffusion with a considerable reduced uncertainty of less then $10 \%$ (Rhee, 2000). We did not apply a correction for seawater since the effect of seawater on the diffusion of dissolved gases is variable (King et al., 1995) and, to our knowledge, no measurements of the $\mathrm{N}_{2} \mathrm{O}$ diffusion in seawater have been published.

$C_{w}$ was taken from the $1^{\circ} \times 1^{\circ}$ seasonal $\mathrm{N}_{2} \mathrm{O}$ fields (DJF, MAM, JJA, SON). For the calculation of $\beta, S c$, and $k_{w}$, seasonal $1^{\circ} \times 1^{\circ}$ fields of wind speed, SST, and salinity were computed from the data sources given above. Atmospheric pressure was set to 1 atm. A mean $x^{\prime}$ of $307 \mathrm{ppb}$ for the period July 1978-July 1997 was calculated from the monthly mean values observed at the Cape Grim (Tasmania) and Adrigole/Mace Head (Ireland) monitoring stations of the ALE/GAGE/AGAGE program (updated version July 2000). The data are available from the anonymous ftp site cdiac.esd.ornl.edu (subdirectory /pub/ale_gage_Agage/Agage/monthly) at the Carbon Dioxide Information Analysis Center in Oak Ridge, Tennessee. $\mathrm{N}_{2} \mathrm{O}$ fluxes were calculated by multiplying the area of a $1^{\circ} \times 1^{\circ}$ square with its flux density calculated as described above. The sum of the $\mathrm{N}_{2} \mathrm{O}$ fluxes of the $1^{\circ} \times 1^{\circ}$ squares yields the total $\mathrm{N}_{2} \mathrm{O}$ emissions from the Arabian Sea (surface area: 6.8 $\times 10^{12} \mathrm{~m}^{2}$ ). The length of one degree of the meridian and the parallel (based on the international ellipsoid) were taken from the tables in Smith (1974).

\section{Results and discussion}

Derived seasonal $\mathrm{N}_{2} \mathrm{O}$ concentration fields are shown in Fig. 3. Elevated $\mathrm{N}_{2} \mathrm{O}$ concentrations occur in coastal areas of the Arabian Sea during JJA (Fig. 3c). During DJF, $\mathrm{N}_{2} \mathrm{O}$ is higher in the eastern than in the western Arabian Sea, whereas during MAM and SON these $\mathrm{N}_{2} \mathrm{O}$ distributions are rather similar (Figs. 3b and 3c). However, the SON database is comparatively small, lending a note of caution to such a
Table 3. $\mathrm{N}_{2} \mathrm{O}$ Fluxes from the Arabian Sea calculated with the $\mathrm{N}_{2} \mathrm{O}$ diffusion coefficient of Rhee (2000)

\begin{tabular}{lcc}
\hline $\mathrm{N}_{2} \mathrm{O}$ Fields & $\begin{array}{c}\text { Flux } \\
\operatorname{Tg~N}_{2} \mathrm{O}\end{array}$ & $\begin{array}{c}\text { Percentage, } \\
\%\end{array}$ \\
\hline $\mathrm{DJF}$ & $0.07 / 0.12 / 0.17$ & $21 / 26 / 24$ \\
$\mathrm{MAM}$ & $0.01 / 0.01 / 0.02$ & $3 / 2 / 3$ \\
$\mathrm{JJA}$ & $0.23 / 0.30 / 0.45$ & $70 / 64 / 64$ \\
$\mathrm{SON}$ & $0.02 / 0.04 / 0.06$ & $6 / 9 / 9$ \\
Sum & $0.33 / 0.47 / 0.70$ & \\
\hline
\end{tabular}

${ }^{a}$ First value calculated according to LM86; second value calculated according to N00, and third value calculated according to W92.

conclusion (Fig. 2d). The seasonal variability in $\mathrm{N}_{2} \mathrm{O}$ concentrations is clearly dominated by coastal upwelling in the Arabian Sea. During the SW monsoon, $\mathrm{N}_{2} \mathrm{O}$-rich subsurface waters are brought to the surface layer (see e.g., Bange et al., 2000; Patra et al., 1999). Interestingly, maximum $\mathrm{N}_{2} \mathrm{O}$ concentrations are found on the eastern Indian continental shelf, consistent with the observations by Patra et al. (1999). However, the calculated $\mathrm{N}_{2} \mathrm{O}$ values in the eastern Arabian Sea $\left(>70^{\circ}\right.$ E) during JJA and SON, 5.8 to $36.3 \mathrm{nmol}$ $\mathrm{L}^{-1}$ (Figs. 3c and 3d), are considerably lower than the 5.3$436 \mathrm{nmol} \mathrm{L}^{-1}$ range recently reported by Naqvi et al. (2000). It is possible that the enormous $\mathrm{N}_{2} \mathrm{O}$ accumulation observed along the Indian coast during the late summer and autumn is in part due to an (anthropogenic?) intensification of the natural coastal hypoxic system as a shift to anoxic conditions in the subsurface layers appears to have occurred in recent years (Naqvi et al., 2000). But if the $\mathrm{N}_{2} \mathrm{O}$ concentrations were high even before this intensification, then our analysis would underestimate the $\mathrm{N}_{2} \mathrm{O}$ concentrations and the associated fluxes from this region, especially during $\mathrm{SON}$ (see below).

Annual $\mathrm{N}_{2} \mathrm{O}$ emissions computed as the sum of the seasonal $\mathrm{N}_{2} \mathrm{O}$ emissions range from 0.37 to $0.78 \mathrm{Tg} \mathrm{N}_{2} \mathrm{O} \mathrm{yr}^{-1}$, depending on which air-sea transfer parameterization is used (Table 2). The use of the $\mathrm{N}_{2} \mathrm{O}$ diffusion coefficient of Rhee (2000) yielded about $10 \%$ lower $\mathrm{N}_{2} \mathrm{O}$ emissions ranging from 0.33 to $0.70 \mathrm{Tg}$ (Table 3 ). Thus, we conclude that previous estimates using the $\mathrm{N}_{2} \mathrm{O}$ diffusion coefficient of Broecker and Peng (1974) may be overestimated. However, we emphasize that the annual flux estimates presented here are associated with a mean relative error of at least $65 \%$ (for further details of the error discussion see Appendices $\mathrm{C}$ and $\mathrm{D}$ ).

$\mathrm{N}_{2} \mathrm{O}$ emissions during the $\mathrm{SW}$ monsoon (JJA) dominate the annual emissions, accounting for about $64-70 \%$ of the total. The second largest contribution occurs during the NE monsoon (DJF) (21-26\%), whereas emissions from the intermonsoon period MAM seems to be of minor importance (2$3 \%$ ). Our revised estimate for the annual $\mathrm{N}_{2} \mathrm{O}$ flux from the Arabian Sea is much more tightly constrained than the previous consensus of $0.16-1.5 \mathrm{Tg} \mathrm{N}_{2} \mathrm{O} \mathrm{yr}^{-1}$ derived using aver- 
Table 4. Summary of various $\mathrm{N}_{2} \mathrm{O}$ flux estimates for the Arabian Sea

\begin{tabular}{lccl}
\hline Source region & $\begin{array}{c}\text { Area, } \\
10^{6} \mathrm{~km}^{2}\end{array}$ & $\begin{array}{c}\text { Flux, } \\
\mathrm{Tg} \mathrm{N}_{2} \mathrm{O} \mathrm{yr}\end{array}$ & References \\
\hline Central, west $\left(>15^{\circ} \mathrm{N}\right)$ & 1.6 & $0.22-0.39$ & Law and Owens (1990) \\
Central, east & 6.2 & 0.44 & Naqvi and Noronha (1991) \\
Central, west & 6.2 & $0.8-1.5$ & Bange et al. (1996a) \\
Central, east & 6.2 & $0.56-1.00$ & Lal and Patra (1998) \\
Central, west & 8.0 & $(0.41-0.75)^{a}$ & Upstill-Goddard et al. (1999) \\
Central, west $\left(>6^{\circ} \mathrm{N}\right)$ & 4.9 & $0.16-0.31$ & Bange et al. (2000) \\
$>15^{\circ} \mathrm{N}$ & 1.6 & $0.10-0.21$ & This study $b$ \\
$>6^{\circ} \mathrm{N}$ & 4.4 & $0.28-0.60$ & \\
$>$ Equator & 6.8 & $0.37^{c}-0.78^{c}$ & \\
\hline
\end{tabular}

${ }^{a}$ Fluxes are calculated according to LM86 (first value) and W92 (second value) unless stated otherwise (see footnotes b and c).

${ }^{b}$ Fluxes are calculated according to LM86 (first value) and the stagnant-film model of Broecker and Peng (1974) (second value).

${ }^{c}$ Flux calculated according to LM86.

${ }^{d}$ Semi-annual flux.

${ }^{e}$ Data calculated with the diffusion coefficient of Broecker and Peng (1974).

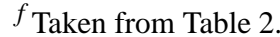

aged in-situ data from a smaller number of studies (Table 4) (Bange et al., 1996a; Bange et al., 2000; Lal and Patra, 1998; Law and Owens, 1990; Naqvi and Noronha, 1991; UpstillGoddard et al., 1999). The data listed in Table 4 depict the "historical" development of published $\mathrm{N}_{2} \mathrm{O}$ flux estimates for the Arabian Sea and show a considerable divergence. However, the fluxes listed are difficult to compare since they were extrapolated to different Arabian Sea surface areas and partly biased by the use of non-seasonal data sets and limited spatial data coverage.

\section{Conclusions}

Our calculated seasonal $\mathrm{N}_{2} \mathrm{O}$ concentration fields and associated air-sea fluxes for the Arabian Sea yield an annual $\mathrm{N}_{2} \mathrm{O}$ flux of $0.33( \pm 0.21)-0.70( \pm 0.46) \mathrm{Tg} \mathrm{N}_{2} \mathrm{O}$. This flux represents approximately $2-35 \%$ of the currently estimated global oceanic $\mathrm{N}_{2} \mathrm{O}$ source of $2-17 \mathrm{Tg} \mathrm{N}_{2} \mathrm{O} \mathrm{yr}^{-1}$ (Bange et al., 1996b; Nevison et al., 1995; Suntharalingam and Sarmiento, 2000). The Arabian Sea is the most intensely studied region for $\mathrm{N}_{2} \mathrm{O}$ emissions in the world ocean. Given its disproportionately large contribution to this total and the lack of adequate coverage in other potentially important oceanographic regimes, the potential marine contribution to atmospheric $\mathrm{N}_{2} \mathrm{O}$ could be somewhat higher than these estimates suggest. Future $\mathrm{N}_{2} \mathrm{O}$ flux estimates could be improved by using $\mathrm{N}_{2} \mathrm{O}$ concentration data from time series measurements at selected stations in the key regions of the Arabian Sea such as the coastal upwelling areas and the central Arabian Sea.

\section{Appendix A: Some useful equations}

Weekly averaged wind speeds in 10 meter height $\left(u_{10}\right.$ in $\mathrm{m} \mathrm{s}^{-1}$ ) for the period July 1987 to December 1995 were derived from satellite-based Special Sensor Microwave/Imager (SSM/I) measurements by using an algorithm developed by Schlüssel (1995):

$$
\begin{aligned}
u_{10}= & c_{0}+c_{1} T_{19 v}+c_{2}\left(T_{19 v}-T_{19 h}\right)+c_{3} T_{22 v} \\
& +c_{4} T_{37 v}+c_{5}\left(T_{37 v}-T_{37 h}\right)
\end{aligned}
$$

$T$ is the brightness temperature in $\mathrm{K} ; v$ and $h$ depict vertical and horizontal polarisations; 19, 22, and 37 depict radiometer channels at $19.35,22.24$, and $37.0 \mathrm{GHz}$, respectively. Values for $c_{i}(i=0, \ldots, 5)$ are listed in Table 5 .

The used 9-point 2-dimensional smoothing procedure (Shuman, 1957) is given as:

$$
\begin{aligned}
z_{i j}= & z_{0}+0.5 v(l-v)\left(z_{2}+z_{4}+z_{6}+z_{8}+4 z_{0}\right) \\
& +0.25 v^{2}\left(z_{1}+z_{3}+z_{5}+z_{7}-4 z_{0}\right) .
\end{aligned}
$$

$z_{0}, \ldots, z_{8}$ stand for the elements in a 9-point grid with $z_{0}$ in the centre. Numbering starts with $z_{1}$ in the upper left corner of the grid and continues counter clockwise. $z_{i j}$ is the resulting value at the grid point coordinates $i$ and $j$; and $v$ is called the smoothing element index of the two smoothing elements, one applied in each dimension. In this study $v$ was set to 0.5 . 

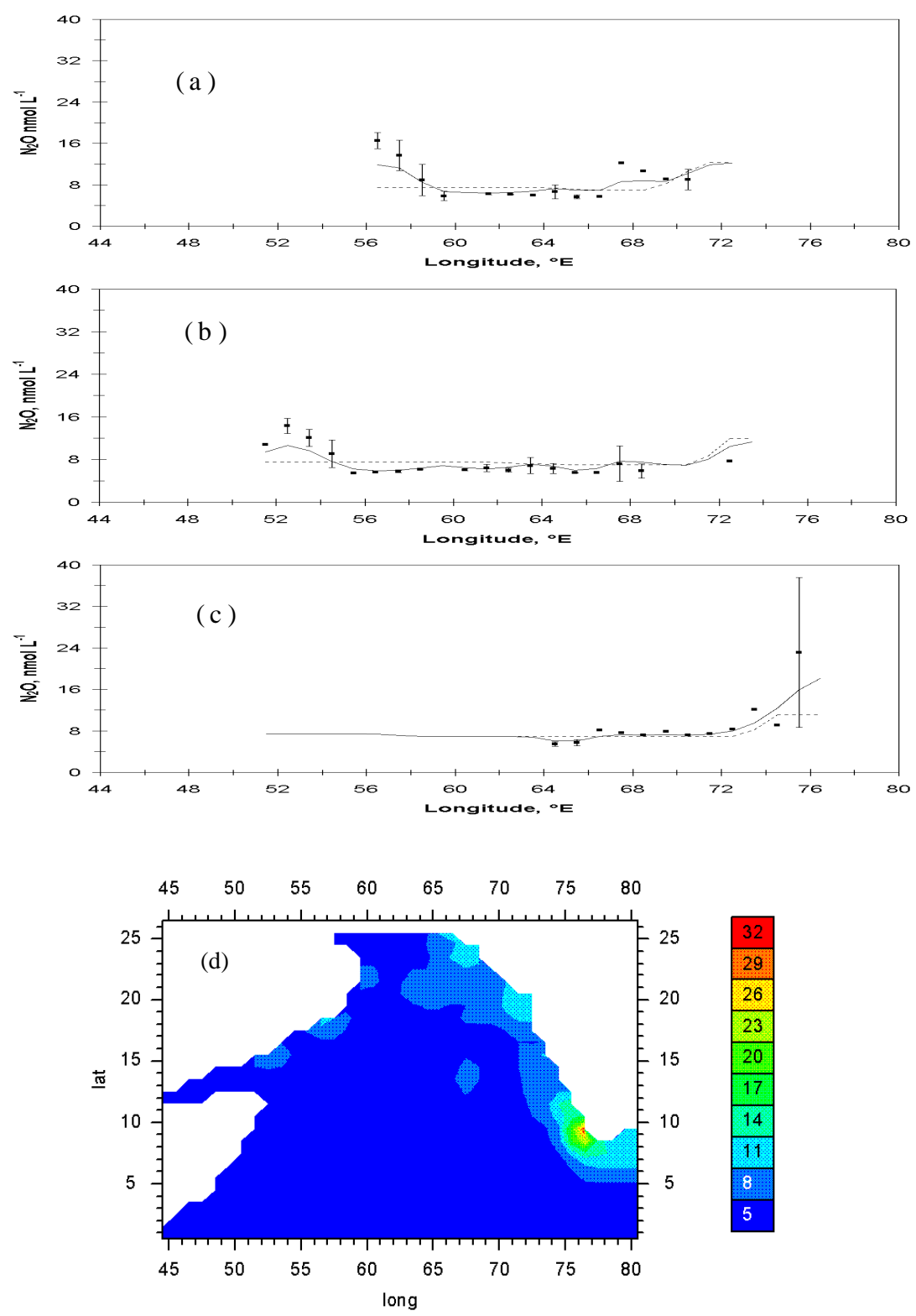

Fig. 4. Annual mean $\mathrm{N}_{2} \mathrm{O}$ concentrations (in nmol L $\mathrm{L}^{-1}$ ) along selected latitudes. The solid line is the predicted $\mathrm{N}_{2} \mathrm{O}$ from the final $1^{\circ} \times 1^{\circ}$ field, the dashed line stands for the smoothed first-guess field, and the solid squares represent the annual mean $\mathrm{N}_{2} \mathrm{O}$ with standard deviation of all measurements within the $1^{\circ} \times 1^{\circ}$ squares along the given latitude. (When less than 3 values were available no standard deviation is given.) (a) $18.5^{\circ} \mathrm{N}$, (b) $15.5^{\circ} \mathrm{N}$, and (c) $10.5^{\circ} \mathrm{N}$. In (d) the corresponding annual mean $\mathrm{N}_{2} \mathrm{O}$ field (in nmol $\mathrm{L}^{-1}$ ) is shown.

The $1^{\circ} \times 1^{\circ} \mathrm{N}_{2} \mathrm{O}$ correction field was computed by applying the distance-weighted interpolation scheme used by Conkright et al. (1994)

$C_{i j}=\frac{\sum_{s=1}^{n} W_{s} Q_{s}}{\sum_{s=1}^{n} W_{s}}$

where $C_{i j}$ is the correction factor at the grid point coordinates $(i, j) ; i$ and $j$ are the coordinates of a grid point in the east-west and north-south directions, respectively; $n$ is the number of observations that fall within the area around the point $i, j$ defined by the influence radius $(R) ; Q_{S}$ is the difference between the observed mean and the first-guess at the $S^{t h}$ point in the influence area; $W_{s}$ is the weight function:

$W_{s}=\exp \left(\frac{-4 r^{2}}{R^{2}}\right)$.

$r$ is the distance of the oberservation from the grid pont $i, j$. When $r>R$, then $W_{s}=0$. In this study the influence radius $R$ was set to $222 \mathrm{~km}$. 

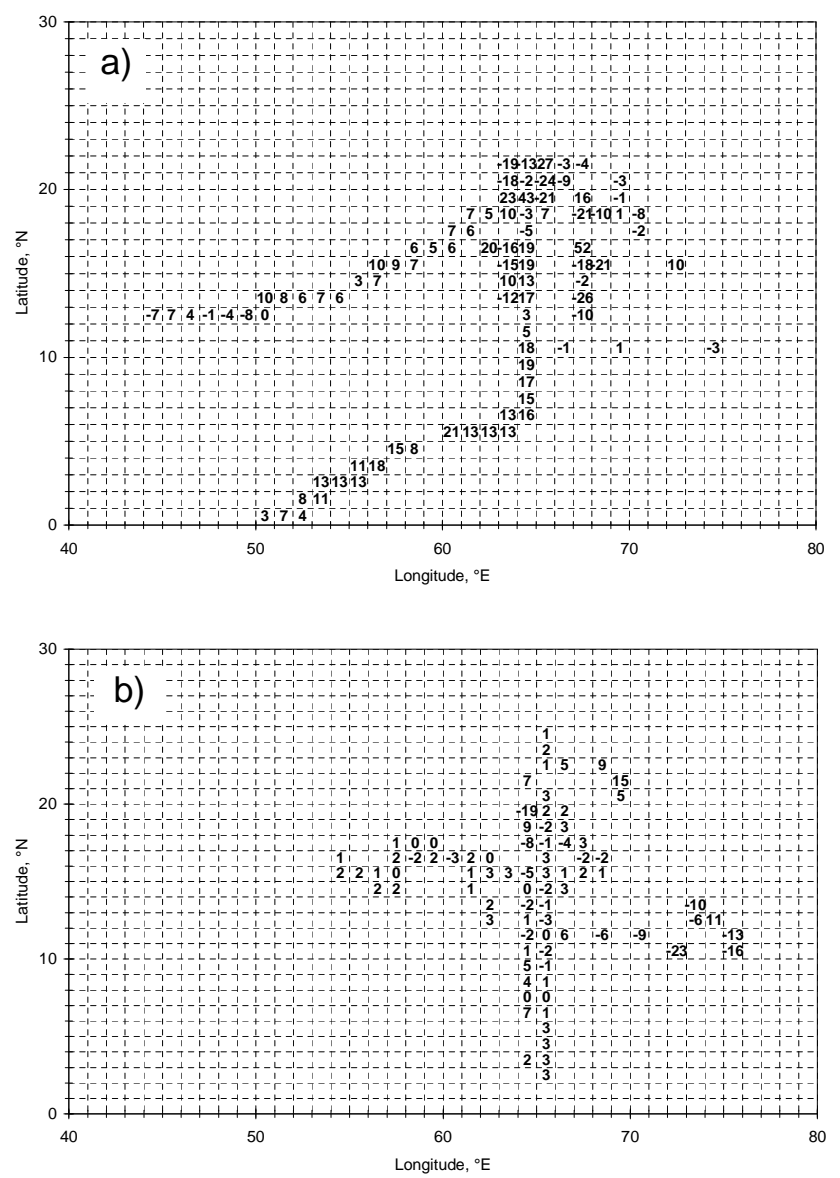

Fig. 5. Relative errors of the final field $1^{\circ} \times 1^{\circ}$ values. (a) DJF, (b) MAM.

\section{Appendix B: Calculation of $k_{w}$}

The approach of Liss and Merlivat (1986) (LM86) consists of three equations for the calculation of $k_{w}\left(\mathrm{in} \mathrm{m} \mathrm{s}^{-1}\right)$ :

$$
\begin{aligned}
& k_{w}=4.7210^{-7} u_{10} \quad\left(u_{10} \leq 3.6 \mathrm{~m} \mathrm{~s}^{-1}\right) \\
& k_{w}=7.9210^{-6} u_{10}-2.6810^{-5}\left(3.6 \mathrm{~m} \mathrm{~s}^{-1}<u_{10}\right. \\
& \leq 13 \mathrm{~m} \mathrm{~s}^{-1} \text { ) } \\
& k_{w}=1.6410^{-5} u_{10}-1.4010^{-4}\left(u_{10}>13 \mathrm{~m} \mathrm{~s}^{-1}\right) \text {. }
\end{aligned}
$$

The LM86 relationship is based on datea obtained from a lake study and a laboratory study at high wind speeds. The approach of Liss and Merlivat (1986) is usually applied with both short-term and long-term wind speeds.

Wanninkhof (1992) (W92) proposed the following relationship for the calculation of $k_{w}$ (in $\mathrm{m} \mathrm{s}^{-1}$ ) with climatological wind speed data:

$k_{w}=1.0810^{-6} \boldsymbol{u}_{10}^{2}$.

This approach is only valid when using long-term averaged (climatological) wind speeds.
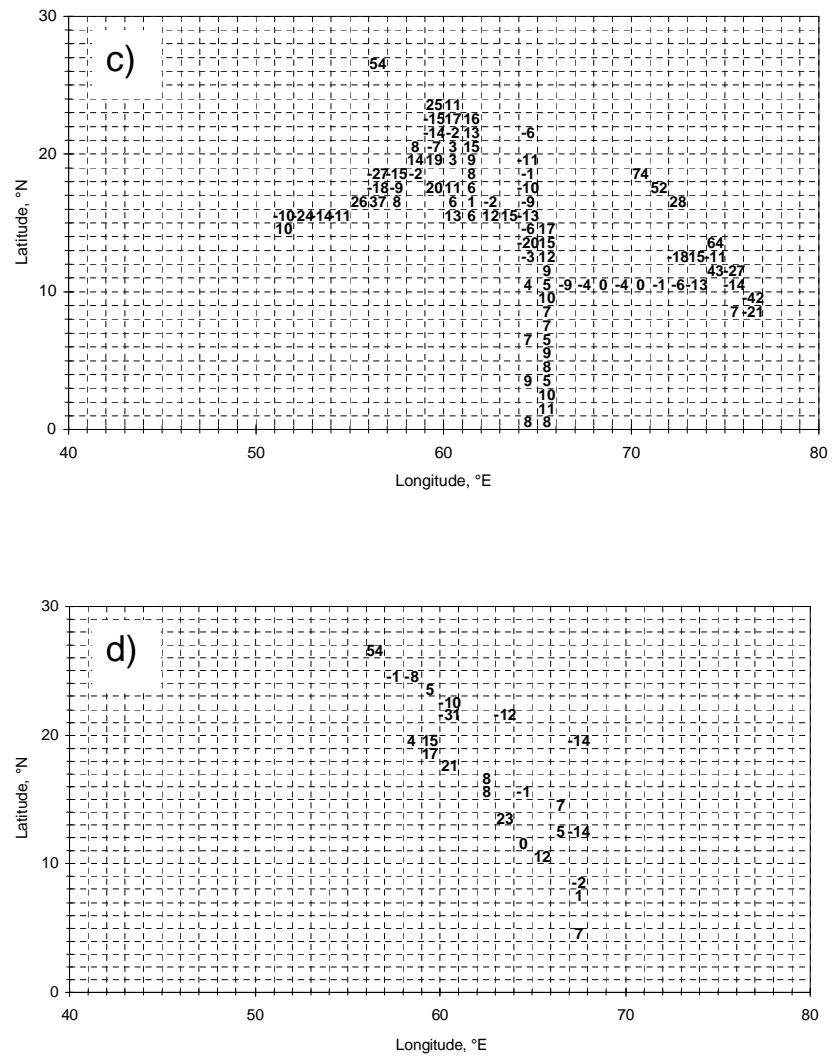

Fig. 5. Continued.: (c) JJA, and (d) SON.

the $k_{w}-u$ relationship of Nightingale et al. (2000)(N00) is given by $\left(k_{w}\right.$ in $\left.\mathrm{m} \mathrm{s}^{-1}\right)$ :

$k_{w}=9.2510^{-7} u_{10}+6.1710^{-7} u_{10}^{2}$.

The N00 relationship shows a dependence on wind speeds intermediate between those of Liss and Merlivat (1986) and Wanninkhof (1992). Moreover, the N00 relationship is in reasonable agreement with estimates of $k_{w}$ based on globally averaged wind speeds.

\section{Appendix C: Error estimate}

In order to evaluate the fit of the computed final $\mathrm{N}_{2} \mathrm{O}$ concentrations to the observations, we compared mean annual $1^{\circ} \times$ $1^{\circ}$ data with the smoothed first-guess field and the final field along selected latitudes (Fig. 4). Figure 5 shows the relative error of the predicted seasonal final fields (the so-called interpolation error), estimated as the difference between the final value in each $1^{\circ} \times 1^{\circ}$ square and the $1^{\circ} \times 1^{\circ}$ pixel data (see Fig. 2). There is a good agreement between predicted values and the observations in the central Arabian Sea during MAM (Fig. 5b). For the monsoon seasons DJF and JJA the relative 
Table 5. Coefficients used in the algorithm for the SSM/I derived wind speeds (Schlüssel, 1995)

\begin{tabular}{lcccccc}
\hline & $\mathrm{c}_{0}$ & $\mathrm{c}_{1}$ & $\mathrm{c}_{2}$ & $\mathrm{c}_{3}$ & $\mathrm{c}_{4}$ & $\mathrm{c}_{5}$ \\
\hline$T_{19 h} \leq 165 \mathrm{~K}$ and $\left(T_{37 v}-T_{37 h}\right) \geq 55 \mathrm{~K}$ & 149.0 & 0.8800 & -0.4887 & -0.4642 & -0.7131 & -0.4668 \\
$165 \mathrm{~K}<T_{19 h} \leq 190 \mathrm{~K}$ and $55 \mathrm{~K}<\left(T_{37 v}-T_{37 h}\right) \leq 20 \mathrm{~K}$ & 205.6 & -0.083449 & -0.07933 & 0.1066 & -0.7346 & -0.9132 \\
\hline
\end{tabular}

$T$ is the brightness temperature in $\mathrm{K} ; v$ and $h$ depict vertical and horizontal polarisations; 19, 22, and 37 depict radiometer channels at 19.35 , 22.24, and $37.0 \mathrm{GHz}$, respectively.

Table 6. Errors used for the error propagation

\begin{tabular}{lcc}
\hline Observable quantity & Mean error & References, remarks \\
\hline Water temperature, $T$ & $\pm 0.5 \mathrm{~K}$ & McClain et al. (1985) \\
Salinity, $S$ & \pm 0.1 & Estimate \\
$\mathrm{N}_{2} \mathrm{O}$ dry mole fraction, $x^{\prime}$ & $\pm 2 \%$ & Estimate \\
Atmospheric pressure, $P$ & $\pm 5 \%$ & Estimate \\
Kinematic viscosity, $v$ & $\pm 1 \%$ & Estimate \\
Diffusion of $\mathrm{N}_{2} \mathrm{O}, D$ & $\pm 10 \%$ & Estimate \\
Wind speed, $u$ & $\pm 1.4 \mathrm{~m} \mathrm{~s}^{-1}$ & Schlüssel (1995) \\
\hline
\end{tabular}

errors of the predicted values are more variable, indicating a considerable underestimation along the coasts of Oman and southwest India, and an overestimation (up to 74\%) along the continental shelf of west India (Fig. 5c). The tendency to focus on measurements in locally restricted features such as coastal upwelling in connection with insufficient seasonal data coverage leads to a bias in the first-guess field. For example, the mean for the INDW province, which covers the eastern coastal Arabian Sea, is strongly influenced by high $\mathrm{N}_{2} \mathrm{O}$ concentrations observed in the southern Indian continental shelf. In contrast, data coverage for the northern continental shelf is poor, and consequently the first-guess field determines the final $\mathrm{N}_{2} \mathrm{O}$ concentration, leading to high uncertainties in this area as indicated by Figs. 5a-5d.

A further uncertainty is introduced by the fact that the $\mathrm{N}_{2} \mathrm{O}$ surface concentrations are depending on SST, salinity, atmospheric pressure and the atmospheric $\mathrm{N}_{2} \mathrm{O}$ mixing ratio which are, at least partly, subject of long term trends due to global change (Barnett et al., 2001; Levitus et al., 2000). For example, the mean tropospheric $\mathrm{N}_{2} \mathrm{O}$ dry mole fractions (see data from the ALE/GAGE/AGAGE program available from the anonymous ftp site cdiac.esd.ornl.edu, subdirectory is given above) increased from about $300 \mathrm{ppb}$ in the late $1970 \mathrm{~s}$ to about $315 \mathrm{ppb}$ in 1999 suggesting a trend of increasing $\mathrm{N}_{2} \mathrm{O}$ surface concentrations. However, a quantification of such trends in sea surface $\mathrm{N}_{2} \mathrm{O}$ concentrations is not possible due to the lack of time series measurements in the Arabian Sea. The seasonal northward shift of the Intertropical
Convergence Zone introduces air masses of southern hemispheric origin with lower $\mathrm{N}_{2} \mathrm{O}$ mole fractions to the Arabian Sea region during the SW monsoon. However, since the mean interhemispheric gradient of $\mathrm{N}_{2} \mathrm{O}$ is only about $0.8 \mathrm{ppb}$ (Prather et al., 2001) we did not account for this effect.

\section{Appendix D: Error propagation}

A rough estimate of the mean error of the flux density $(F)$, introduced by the uncertainties of the observables (i.e. $T, S, u, P$, and $x^{\prime}$ ), was calculated according to the following equations:

$$
\begin{aligned}
\Delta F & =\sqrt{\left(\frac{\partial F}{\partial C_{w}} \Delta C_{w}\right)^{2}+\left(\frac{\partial F}{\partial C_{a}} \Delta C_{a}\right)^{2}} \\
& \sqrt{+\left(\frac{\partial F}{\partial k_{w}} \Delta k_{w}\right)^{2}+\left(\frac{\partial F}{\partial S c} \Delta S c\right)^{2}} \\
\Delta C_{a} & =\sqrt{\left(\frac{\partial C_{a}}{\partial x^{\prime}} \Delta x^{\prime}\right)^{2}+\left(\frac{\partial C_{a}}{\partial \beta} \Delta \beta\right)^{2}+\left(\frac{\partial C_{a}}{\partial P} \Delta P\right)^{2}} \\
\Delta \beta & =\sqrt{\left(\frac{\partial \beta}{\partial T} \Delta T\right)^{2}+\left(\frac{\partial \beta}{\partial S} \Delta S\right)^{2}} \\
\Delta k_{w} & =\frac{\partial k_{w}}{\partial u} \Delta u \\
\Delta S c & =\sqrt{\left(\frac{\partial S c}{\partial \boldsymbol{D}_{N 2 O}} \Delta \boldsymbol{D}_{N 2 O}\right)^{2}+\left(\frac{\partial S c}{\partial v} \Delta v\right)^{2}}
\end{aligned}
$$

where $v$ stands for the kinematic viscosity of seawater and the operator $\partial / \partial$ depicts the partial differential. For a strict treatment of the error propagation, the standard deviation of each parameter should be known. Since this was not the case, we replaced the standard deviation partly with best estimates of the mean error (depicted by the $\Delta$ symbol, data listed in Table 6). For $\Delta C_{w}$ we used the mean relative error (i.e. the interpolation error) calculated from the seasonal data shown in Fig. 5 (see also the Appendix A: Error estimate). We calculated the relative error $\Delta F / F$ for each $1^{\circ} \times 1^{\circ}$ square of the four seasonal $\mathrm{N}_{2} \mathrm{O}$ fields. Table 7 gives an overview of the resulting mean relative errors of the seasonal flux densities. Not surprisingly, the lowest mean relative error of $C_{w}$ is associated with highest relative error of resulting flux 
Table 7. Overview of the mean relative errors of $\mathrm{N}_{2} \mathrm{O}$ surface concentrations and $\mathrm{N}_{2} \mathrm{O}$ flux densities

\begin{tabular}{lcc}
\hline & $\begin{array}{c}\text { Mean } \Delta C_{w} / C_{w}, \\
\pm \%\end{array}$ & $\begin{array}{c}\text { Mean } \Delta F / F, \\
\pm \%\end{array}$ \\
\hline DJF & 11 & 75 \\
MAM & 4 & 330 \\
JJA & 14 & 79 \\
SON & 12 & 442 \\
\hline
\end{tabular}

densities. During MAM the dissolved $\mathrm{N}_{2} \mathrm{O}$ concentrations are low and resulting in only small concentration differences $\left(C_{w}-C_{a}\right)$ across the ocean-atmosphere interface which in turn lead to high mean relative errors of the flux densities. During the monsoon season JJA, $\mathrm{N}_{2} \mathrm{O}$ concentrations in the coastal upwelling zones are considerable higher causing a higher mean relative error of $C_{w}$ and comparable low mean relative errors of the resulting flux density. The mean relative errors for the seasonal flux densities yield the overall mean relative error of the annual $\mathrm{N}_{2} \mathrm{O}$ emissions from the Arabian Sea of at least $65 \%$. Systematic errors caused by uncertainties in parameterizations such as $\mathrm{N}_{2} \mathrm{O}$ diffusion in seawater (determination of the $\mathrm{N}_{2} \mathrm{O}$ diffusion have not been made in seawater-like systems (see literature compilation in Rhee, 2000)) and air-sea exchange approaches are not accounted for in this estimate (see Results and discussion). Moreover, it is important to keep in mind that the calculation of any climatological data fields are biased by the chosen smoothing and averaging routines (see e.g. Sterl, 2001).

A detailed analysis of errors introduced by different filling routines, averaging procedures etc. is beyond the scope of this study. Generally, gas exchange estimates suffer from the fact that a direct (i.e. at sea) determination of the processes responsible for the gas exchange across the oceanatmosphere interface is still a technological challenge (Frost and Upstill-Goddard, 1999; Jähne and Haußecker, 1998).

Acknowledgements. We acknowledge the invaluable help of the officers and crews of the various research vessels involved. HWB thanks S. van Dijk, J. Kettle, and A. Suthhof for inspiring discussions and C. Strametz for help with the manuscript. The investigations were supported by the U.K. Natural Environment Research Council (NERC) Arabesque initiative, the German Bundesministerium für Bildung, Wissenschaft, Forschung und Technologie (grants 03F0137A, 03F0183G, 03F0241C), and the Max Planck Society, and the Institute for Marine Research, Kiel.

\section{References}

Bange, H. W., Rapsomanikis, S., and Andreae, M. O.: Nitrous oxide emissions from the Arabian Sea, Geophys. Res. Lett., 23, 31753178, 1996a.
Bange, H. W., Rapsomanikis, S., and Andreae, M. O.: Nitrous oxide in coastal waters, Global Biogeochem. Cycles, 10, 197-207, 1996b.

Bange, H. W., Rixen, T., Johansen, A. M., Siefert, R. L., Ramesh, R., Ittekkot, V., Hoffmann, M. R., and Andreae, M. O.: A revised nitrogen budget for the Arabian Sea, Global Biogeochem. Cycles, 14, 1283-1298, 2000.

Barnett, T. P., Pierce, D. W., and Schnur, R.: Detection of anthropogenic climate change in the world's oceans, Science, 292, 270274, 2001.

Broecker, W. S. and Peng, T.-S.: Gas exchange rates between air and sea, Tellus, 26, 21-35, 1974.

Codispoti, L. A., Elkins, J. W., Yoshinari, T., Friederich, G. E., Sakamoto, C. M., and Packard, T. T.: On the nitrous oxide flux from productive regions that contain low oxygen waters, in Oceanography of the Indian Ocean, edited by B. N. Desai, 271284, Oxford Publishing, New Delhi, 1992.

Conkright, M., Levitus, S., and Boyer, T. P.: NOAA Atlas NESDIS 1, World Ocean Atlas 1994, Volume 1: Nutrients, National Environmental Satellite, Data, and Information Service, National Oceanic and Atmospheric Administration, US Department of Commerce, Washington DC, 1994.

Frost, T. and Upstill-Goddard, R. C.: Air-sea exchange into the millennium: Progress and uncertainties, Oceanogr. Mar. Biol. Ann. Rev., 37, 1-45, 1999.

Jähne, B., and Haußecker, H.: Air-water gas exchange, Annual Rev. Fluid Mech., 30, 69-91, 1998.

Kettle, A. J., Andreae, M. O., Amouroux, D., Andreae, T. W., Bates, T. S., Berresheim, H., Bingemer, H., Boniforti, R., Curran, M. A. J., DiTullio, G. R., Helas, G., Jones, G. B., Keller, M. D., Kiene, R. P., Leck, C., Levasseur, L., Malin, G., Maspero, M., Matrai, P., McTaggart, A. R., Mihalopoulos, N., Nguyen, B. C., Novo, A., Putaud, J. P., Rapsomanikis, S., Roberts, G., Schebeske, G., Sharma, S., Simo, R., Staubes, R., Turner, S., and Uher G.: A global database of sea surface dimethylsulfide (DMS) measurements and a procedure to predict sea surface DMS as a function of latitude, longitude, and month, Global Biogeochem. Cycles, 13, 399-444, 1999.

King, D. B., De Bryun, W. J., Zheng, M., and Saltzman, E. S.: Uncertainties in the molecular diffusion coefficient of gases in water for the estimation of air-sea exchange, in Air-water gas transfer, edited by B. Jähne and E. C. Monahan, pp. 13-22, AEON Verlag \& Studio, Hanau, Germany, 1995

Lal, S. and Patra, P. K.: Variabilities in the fluxes and annual emissions of nitrous oxide from the Arabian Sea, Global Biogeochem. Cycles, 12, 321-327, 1998.

Law, C. S. and Owens, N. J. P.: Significant flux of atmospheric nitrous oxide from the northwest Indian Ocean, Nature, 346, 826828,1990

Levitus, S., Antonov, J. I., Boyer, T. P., and Stephens, C.: Warming of the Ocean, Science, 287, 2225-2229, 2000.

Liss, P. S. and Merlivat, L.: Air-sea exchange rates: Introduction and synthesis, in The Role of Air-Sea Exchange in Geochemical Cycling, edited by P. Buat-Ménard, 113-127, D. Reidel Publishing Company, Dordrecht, 1986

Longhurst, A.: Ecological geography of the sea, 398 pp., Academic Press, San Diego, 1998.

McClain, E. P., Pichel, W. G., and Walton, C. C.: Comparative performance of AVHRR-based multichannel sea surface tempera- 
tures, J. Geophys. Res., 90, 11, 587-11, 601, 1985.

Naqvi, S. W. A., Jayakumar, D. A., Narveka, P. V., Naik, H., Sarma, V. V. S. S., D'Souza, W., Joseph, S., and George, M. D.: Increased marine production of $\mathrm{N}_{2} \mathrm{O}$ due to intensifying anoxia on the Indian continental shelf, Nature, 408, 346-349, 2000.

Naqvi, S. W. A. and Noronha, R. J.: Nitrous oxide in the Arabian Sea, Deep-Sea Res., 38, 871-890, 1991.

Naqvi, S. W. A., Yoshinari, T., Jayakumar, D. A., Altabet, M. A., Narvekar, P. V., Devol, A. H., Brandes, J. A., and Codispoti, L. A.: Budgetary and biogeochemical implications of $\mathrm{N}_{2} \mathrm{O}$ isotope signatures in the Arabian Sea, Nature, 394, 462-464, 1998.

Nevison, C. D., Weiss, R. F., and Erickson III, D. J.: Global oceanic emissions of nitrous oxide, J. Geophys. Res., 100, 15, 809-15, $820,1995$.

Nightingale, P., Malin, G., Law, C. S., Watson, A. J., Liss, P. S., Liddicoat, M. I., Boutin, J., and Upstill-Goddard, R. C.: In-situ evaluation of air-sea gas exchange parameterizations using novel conservative and volatile tracers, Global Biogeochem. Cycles, 14, 373-387, 2000.

Patra, P. K., Lal, S., Venkataramani, S., De Sousa, S. N., Sarma, V. V. S. S., and Sardesai, S.: Seasonal and spatial variability in $\mathrm{N}_{2} \mathrm{O}$ distribution in the Arabian Sea, Deep-Sea Res. I, 46, 529543, 1999.

Prather, M., Ehhalt, D., Dentener, F., Derwent, R., Dlugokencky, E., Holland, E., Isaksen, I., Katima, J., Kirchhoff, V., Matson, P., Midgley, P., and Wang, M.: Atmospheric chemistry and greenhouse gases, in Climate Change 2001: The Scientific Basis. Contribution of Working Group I to the Third Assessment Report of the Intergovernmental Panel on Climate Change, edited by Houghton, J. T., Ding, Y., Griggs, D. J., Noguer, M., Van der Linden, P. J., Dai, X., Maskell, K., and Johnson, C. A., 239-287, Cambridge University Press, Cambridge, UK, 2001.

Rhee, T. S.: The process of air-water gas exchange and its application, $\mathrm{PhD}$ thesis, Texas A \& M University, College Station, 2000. Schlüssel, P.: Passive Fernerkundung der unteren Atmosphäre und der Meeresoberfläche aus demWeltraum, Habilitationsschrift Ber. A20, 175 pp., Zentrum für Meeres- und Klimaforschung der Universität Hamburg, Germany, 1995.

Seitzinger, S. P., Kroeze, C., and Styles, R. V.: Global distribution of $\mathrm{N}_{2} \mathrm{O}$ emissions from aquatic systems: Natural emissions and anthropogenic effects, Chemosphere: Global Change Sci., 2, 267-279, 2000.

Shuman, F. G.: Numerical methods in weather prediction: II. Smoothing and filtering, Mon. Weath. Rev., 85, 357-361, 1957.

Siedler, G. and Peters, H.: Properties of sea water, in Oceanography, Landolt-Börnstein New Ser., Group V, vol. 3a, edited by Sündermann, J., 233-264, Springer Verlag, New York, 1986.

Smith, F. G. W. (Ed.): CRC Handbook of Marine Science, vol. I, 627 pp., CRC Press Inc., Boca Raton, 1974

Sterl, A.: On the impact of gap-filling algorithms on variability patters of reconstructed oceanic surface fields, Geophys. Res. Lett., 28, 2473-2476, 2001.

Suntharalingam, P. and Sarmiento, J. L.: Factors governing the oceanic nitrous oxide distribution: Simulations with an ocean general circulation model, Global Biogeochem. Cycles, 14, 429454, 2000.

Upstill-Goddard, R. C., Barnes, J., and Owens, N. J. P.: Nitrous oxide and methane during the $1994 \mathrm{SW}$ monsoon in the Arabian Sea/northwestern Indian Ocean, J. Geophys. Res., 104, 30, 067 30, 084, 1999.

Wanninkhof, R.: Relationship between wind speed and gas exchange over the ocean, J. Geophys. Res., 97, 7373-7382, 1992.

Weiss, R. F. and Price, B. A.: Nitrous oxide solubility in water and seawater, Mar. Chem., 8, 347-359, 1980.

Weiss, R. F., Van Woy, F. A., and Salameh, P. K.: Surface water and atmospheric carbon dioxide and nitrous oxide observations by shipboard automated gas chromatography: Results from expeditions between 1977 and 1990, Carbon Dioxide Information Analysis Center, Oak Ridge National Laboratory, Oak Ridge, Tennessee, USA, 1992. 